Т. О. Грабовська

Білочерківський національний аграрний університет

\title{
ОЦІНКА ТА ДОБІР ЗРАЗКІВ КУКУРУДЗИ ПЛАЗМИ АЙОДЕНТ НА ПОСУХОСТІЙКІСТЬ ФІЗІОЛОГІЧНИМИ МЕТОДАМИ
}

\begin{abstract}
Проведено комплексну оцінку зразків кукурудзи на посухостійкість фізіологічними методами. Доведено, що зразки, які були пророщені на осмотичних розчинах сахарози з поступовим збільшенням тиску, мають більшу водоутримувальну здатність та більший вміст зв'язаної води. Також у відібраних зразків менший відсоток гідролізованого крохмалю у клітинах кореневого чохлика.
\end{abstract}

T. O. Grabovskaya

Bila Tserkva National Agrarian University

\section{ESTIMATION AND SELECTION OF PLASMA IODENT CORN SAMPLES ON DROUGHT-RESISTANCE BY PHYSIOLOGICAL METHODS}

The complex estimation of corn samples on drought-resistance was conducted by physiological methods. It was proven that samples which grown on osmotic solutions of sucrose with the gradual increase of pressure have greater water-retaining ability and greater content of bound-water. Also in the selected samples the less percent of hydrolyzed starch in the cells of root caps was indicated.

\section{Вступ}

Проблема підвищення посухостійкості рослин - одна з найпоширеніших у світі. Глобальне потепління клімату останніми роками призвело до зменшення суми опадів улітку та збільшення кількості днів із температурою повітря понад $+30^{\circ} \mathrm{C}$. Відомо, що у кукурудзи підвищення температури на $1{ }^{\circ} \mathrm{C}$ понад оптимальну призводить до зниження урожаю на 3 \% [9]. Тому отримання стабільних урожаїв кукурудзи залежить від упровадження у виробництво гібридів, які поєднують високу продуктивність та стійкість до підвищених температур і обмеженого водопостачання, що передбачає щільну взаємодію селекції з фізіологічними дослідженнями [8].

Процес адаптації рослин до стресів інтегрує різноманітні пристосувальні зміни, які відбуваються в організмі рослин. Окремо визначені ознаки не дають повної інформації про стійкість рослин до дії посухи. Пошук надійних критеріїв оцінки стійкості має ряд серйозних труднощів, обумовлених складністю самої ознаки, яка являє собою взаємодію організму та середовища. Комплексна діагностика фізіолого-біохімічними та селекційними методами дозволяє досить об'єктивно характеризувати вихідний матеріал. Тому наша робота спрямована на використання розчинів сахарози як фону для проведення добору вихідного матеріалу у процесі селекції з поступовим збільшенням осмотичного тиску розчинів у наступних циклах добору та генераціях самозапилення з метою отримання посухостійких генотипів. Мета цієї роботи - оцінити та відібрати новий вихідний посухостійкий матеріал кукурудзи плазми Айодент, адаптований до дії стресових умов Степової зони України та ідентифікований за допомогою фізіологічних методів.

(C) Т. О. Грабовська, 2009

44 


\section{Матеріал і методи досліджень}

Вивчення рослин проводили в лабораторії фізіології кукурудзи Інституту зернового господарства УААН протягом 2004-2006 років. Як вихідний матеріал використовували 22 зразки скоростиглого синтетика плазми Айодент $\left(\mathrm{S}_{3}-\mathrm{S}_{6}\right)$, попередньо відібрані на стійкість до стресових умов. Визначення фізіологічних ознак досліджених зразків кукурудзи проводили у фазі 14-15 листків, фазі цвітіння волоті, фазі молочної стиглості зерна. Для досліджень брали 3-4-й (верхній) листок із 5-6 типових рослин кожного зразка кукурудзи, що вивчався.

Для визначення посухостійкості використовували на проростках лабораторні методи, такі як метод гідролізу статолітного крохмалю в клітинах кореневого чохлика [5] та метод набубнявіння насінин в осмотичних розчинах [6]. У літній період зразки оцінювали на посухостійкість методом визначення вільної та зв'язаної води [2; 6], методом визначення водоутримувальної здатності шляхом прив'ялювання зрізаних листків [7] та методом визначення електричного опору тканин листків [5].

Статистичну достовірність експериментальних даних визначали за допомогою дисперсійного аналізу за Б. А. Доспєховым [4].

\section{Результати та їх обговорення}

Для збільшення посухостійкості вихідного матеріалу кукурудзи використовували метод пророщення насіння на осмотичних розчинах сахарози у процесі створення ліній. Із кожною наступною генерацією проводився добір стійких форм на концентрованіших осмотичних розчинах сахарози порівняно з контрольними зразками. Концентрацію сахарози для посилення добору збільшували з кожним наступним інбридингом, але також залишали постійний фон добору (18 атм., а у подальшому - 20 атм.) для виявлення адаптаційного потенціалу відібраних генотипів (рис. 1). Для контролю паралельно висаджували сухе насіння. Самозапилення проводили на контрольних та відібраних рослинах.

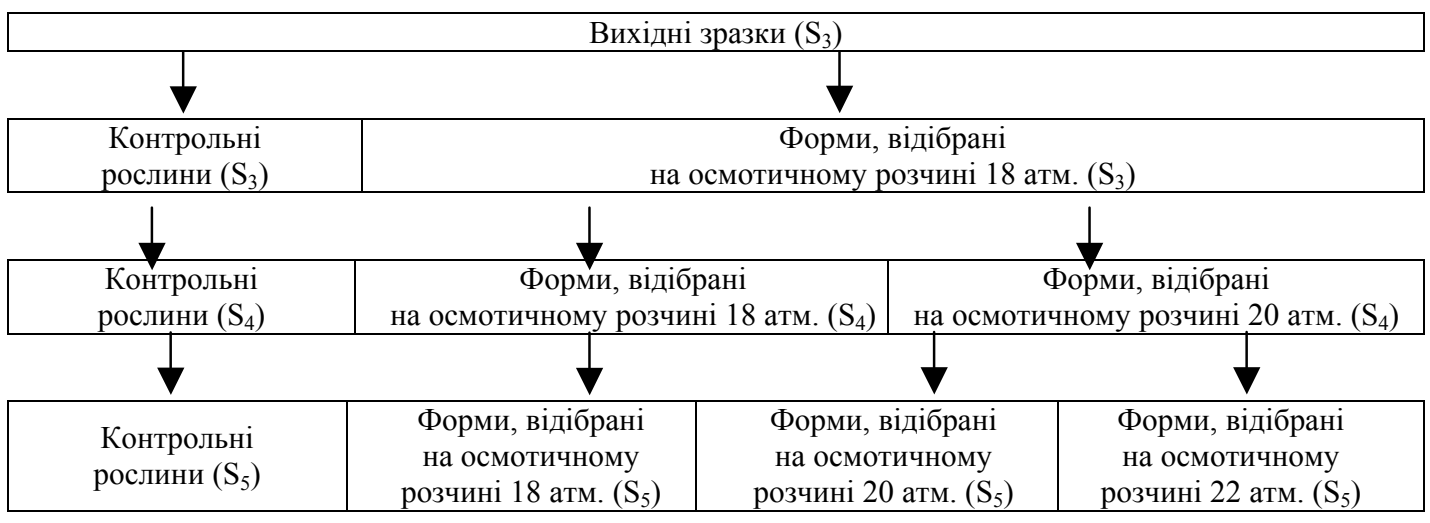

Рис. 1. Схема добору посухостійких ліній

на осмотичних розчинах різних концентрацій у процесі інбридингу

Умовна назва зразків, відібраних при 18 атм. - ПК (1-22)-18; зразків, відібраних при 20 атм. - ПК (1-22)-20; зразків, відібраних при 22 атм. - ПК (1-22)-22, де ПК - посухостійка кукурудза, 1-22 - номер зразка, 18, 20, 22 - осмотичний тиск фону добору.

Одна $з$ особливостей посухостійких рослин - їх здатність зберігати синтетичні процеси в умовах посухи. У нестійких рослин переважають гідролітичні процеси [2]. 
Відібрані зразки мали високі показники посухостійкості. Зниження вмісту гідролізованого крохмалю після дії розчину хлористого натрію на корінці проростків у 2004 році відбулося на $8 \%$, у 2005 - на $12 \%$, й у 2006 - теж на $12 \%$ (табл. 1).

Таблиия 1

Оцінка відібраних зразків кукурудзи на посухостійкість методом гідролізу статолітного крохмалю

\begin{tabular}{|c|c|c|c|c|c|c|c|c|c|}
\hline \multirow{3}{*}{ Зразки } & \multicolumn{2}{|c|}{2005 p. $\left(S_{4}\right)$} & \multicolumn{3}{|c|}{$2006 \mathrm{p} .\left(\mathrm{S}_{5}\right)$} & \multicolumn{4}{|c|}{2007 p. $\left(S_{6}\right)$} \\
\hline & \multicolumn{9}{|c|}{ фон добору, \% гідролізованого крохмалю } \\
\hline & контроль & 18 атм. & контроль & 18 атм. & 20 атм. & контроль & 18 атм. & 20 атм. & 22 атм. \\
\hline ПК 3 & $25 \pm 1,71$ & $14 \pm 0,22$ & $25 \pm 1,11$ & $10 \pm 0,32$ & $10 \pm 1,00$ & $28 \pm 1,03$ & $11 \pm 0,22$ & $10 \pm 0,49$ & $11 \pm 0,45$ \\
\hline ПК 7 & $29 \pm 0,70$ & $26 \pm 0,38$ & $28 \pm 1,69$ & $22 \pm 1,08$ & $20 \pm 2,00$ & $24 \pm 0,32$ & $23 \pm 1,05$ & $15 \pm 0,68$ & $12 \pm 0,79$ \\
\hline ПК 8 & $29 \pm 0,33$ & $27 \pm 1,14$ & $33 \pm 1,02$ & $30 \pm 1,10$ & $32 \pm 1,15$ & $26 \pm 0,83$ & $24 \pm 1,08$ & $27 \pm 0,72$ & $26 \pm 0,44$ \\
\hline ПК 9 & $10 \pm 0,41$ & $4 \pm 0,25$ & $5 \pm 0,50$ & $3 \pm 0,11$ & $3 \pm 0,16$ & $7 \pm 0,51$ & $5 \pm 0,30$ & $5 \pm 0,65$ & $5 \pm 0,23$ \\
\hline ПК 10 & $18 \pm 0,71$ & $4 \pm 0,36$ & $17 \pm 0,61$ & $6 \pm 0,41$ & $5 \pm 0,20$ & $8 \pm 0,57$ & $4 \pm 0,30$ & $4 \pm 0,76$ & $3 \pm 0,50$ \\
\hline ПК 12 & $30 \pm 1,25$ & $14 \pm 0,89$ & $19 \pm 0,83$ & $5 \pm 0,38$ & $6 \pm 0,32$ & $21 \pm 0,68$ & $13 \pm 0,73$ & $10 \pm 0,82$ & $7 \pm 0,85$ \\
\hline ПК 13 & \begin{tabular}{|l|}
$14 \pm 0,36$ \\
\end{tabular} & $10 \pm 0,87$ & $17 \pm 0,71$ & $10 \pm 0,65$ & $9 \pm 0,30$ & $20 \pm 0,25$ & $8 \pm 0,56$ & $9 \pm 0,22$ & $11 \pm 0,35$ \\
\hline ПК 15 & \begin{tabular}{|l|}
$20 \pm 0,89$ \\
\end{tabular} & $14 \pm 0,99$ & $21 \pm 0,71$ & $11 \pm 0,58$ & $16 \pm 1,58$ & $32 \pm 0,38$ & $25 \pm 0,89$ & $28 \pm 0,96$ & $33 \pm 0,89$ \\
\hline ПК 16 & $11 \pm 0,57$ & $2 \pm 0,20$ & $5 \pm 0,38$ & $0 \pm 0$ & $6 \pm 0,60$ & $9 \pm 0,30$ & $8 \pm 0,22$ & $10 \pm 0,83$ & $11 \pm 0,15$ \\
\hline ПК 17 & $5 \pm 0,10$ & $2 \pm 0,09$ & $4 \pm 0,25$ & $0 \pm 0$ & $0 \pm 0$ & $5 \pm 0,60$ & $8 \pm 0,90$ & $3 \pm 0,10$ & $2 \pm 0,10$ \\
\hline ПК 18 & $22 \pm 1,00$ & $10 \pm 1,05$ & $16 \pm 0,20$ & $13 \pm 0,15$ & $2 \pm 0,10$ & $14 \pm 1,02$ & $8 \pm 0,50$ & $7 \pm 0,32$ & $4 \pm 0,25$ \\
\hline ПК 19 & $34 \pm 1,85$ & $17 \pm 0,64$ & $27 \pm 1,55$ & $23 \pm 0,96$ & $15 \pm 0,72$ & $26 \pm 0,63$ & $22 \pm 1,09$ & $14 \pm 0,55$ & $11 \pm 0,71$ \\
\hline ПК 26 & $8 \pm 0,69$ & $5 \pm 0,33$ & $4 \pm 0,23$ & $0 \pm 0$ & $2 \pm 0,80$ & $9 \pm 0,82$ & $3 \pm 0,20$ & $2 \pm 0,10$ & $4 \pm 0,20$ \\
\hline ПК 27 & $30 \pm 1,03$ & $27 \pm 1,85$ & $35 \pm 1,66$ & $25 \pm 0,91$ & $14 \pm 0,59$ & $26 \pm 0,96$ & $22 \pm 0,92$ & $16 \pm 0,95$ & $11 \pm 0,86$ \\
\hline ПК 28 & $33 \pm 0,84$ & $31 \pm 1,05$ & $31 \pm 0,90$ & $24 \pm 0,85$ & $23 \pm 1,30$ & $28 \pm 0,95$ & $25 \pm 1,33$ & $12 \pm 1,36$ & $12 \pm 0,95$ \\
\hline ПК 29 & $44 \pm 0,66$ & $25 \pm 1,64$ & $37 \pm 1,90$ & $24 \pm 1,25$ & $26 \pm 1,22$ & $36 \pm 1,85$ & $25 \pm 0,80$ & $20 \pm 0,82$ & $21 \pm 1,00$ \\
\hline ПК 30 & $13 \pm 0,41$ & $12 \pm 0,77$ & $11 \pm 0,56$ & $10 \pm 1,13$ & $9 \pm 0,60$ & $15 \pm 0,55$ & $12 \pm 0,65$ & $15 \pm 1,09$ & $20 \pm 0,80$ \\
\hline ПК 31 & $11 \pm 0,41$ & $5 \pm 0,20$ & $6 \pm 0,64$ & $4 \pm 0,50$ & $0 \pm 0$ & $8 \pm 0,71$ & $6 \pm 0,45$ & $4 \pm 0,65$ & $4 \pm 0,30$ \\
\hline ПІК 32 & $15 \pm 0,25$ & $12 \pm 0,90$ & $13 \pm 0,25$ & $9 \pm 0,90$ & $12 \pm 0,30$ & $12 \pm 0,25$ & $10 \pm 1,05$ & $12 \pm 0,87$ & $13 \pm 0,66$ \\
\hline ПІК 33 & $30 \pm 1,03$ & $19 \pm 1,00$ & $24 \pm 1,06$ & $14 \pm 0,64$ & $5 \pm 0,35$ & $25 \pm 1,00$ & $12 \pm 0,97$ & $9 \pm 0,94$ & $8 \pm 0,59$ \\
\hline ПІК 35 & $8 \pm 0,71$ & $5 \pm 0,64$ & $6 \pm 0,80$ & $4 \pm 0,25$ & $2 \pm 0,25$ & $11 \pm 0,65$ & $5 \pm 0,64$ & $2 \pm 0,10$ & $4 \pm 0,54$ \\
\hline ПК 40 & $20 \pm 1,55$ & $10 \pm 1,00$ & $22 \pm 0,69$ & $6 \pm 0,20$ & $4 \pm 0,20$ & $15 \pm 0,39$ & $4 \pm 0,30$ & $2 \pm 0,25$ & $0 \pm 0$ \\
\hline Середнє & 22 & 13 & 20 & 12 & 10 & 20 & 13 & 11 & 11 \\
\hline $\mathrm{HIP}_{0,05}$ & 1,8 & 1,5 & 1,6 & 1,5 & 1,5 & 1,7 & 1,8 & 1,5 & 1,6 \\
\hline $\begin{array}{l}\mathrm{HIP}_{0,053 \mathrm{a}} \\
\text { групами }\end{array}$ & \multicolumn{2}{|c|}{1,8} & \multicolumn{3}{|c|}{1,7} & \multicolumn{4}{|c|}{1,1} \\
\hline
\end{tabular}

Примітки: НІР 0,05 - найменша істотна різниця за Б. А. Доспєховим; контроль - контрольні рослини; 18, 20, 22 атм. - осмотичний тиск фону добору; ПК 3 - ПК 40 - робоча назва зразків; $\mathrm{S}_{4}-\mathrm{S}_{6}-$ цикл самозапилення ліній у процесі їх створення.

Деякі зразки негативно відреагували на збільшення осмотичного розчину (ПК 8 , ПК 15, ПК 16, ПК 30). Ці форми мали відносно стабільні показники за постійного фону пророщування (18 атм.), але у жорсткіших умовах (20, 22 атм.) спостерігалось незначне наростання відсотків гідролізованого крохмалю. Узагалі, вся популяція відрізнялася високими показниками вмісту крохмалю у кореневому чохлику після зневоднення, тобто характеризувалась як високопосухостійка згідно з цим показником.

Інтенсивність набубнявіння насіння має велике значення при проростанні, особливо коли спостерігається весняна посуха і запаси вологи у грунті мінімальні. Тому наступним методом, який ми використовували для оцінки матеріалу, був метод набубнявіння насінин в осмотичному розчині $2 \mathrm{M} \mathrm{NaCl}$, що характеризує потужність сисної сили насіння зразків. Ефективність добору простежується майже в усіх зразків, які підвищували здатність поглинати воду з осмотичного розчину досить великої концентрації. У 2005 р. відібрані рослини порівняно з контрольними зразками на 4,8 \% більше поглинали води із сольового розчину, у 2006 р. рослини, відібрані при 18 атм., погли- 
нали води більше на 3,9 \%, при 20 атм. - на 5,5\%, у 2007 р. при 18 атм. - на 3,5 \%, при 20 атм. - на 4,4 \%, при 22 атм. - на 7,1 \% (табл. 2). Генотипи ПК 8-20, ПК 30-20 у 2006 р. знижували показники порівняно з такими, пророщеними при осмотичному тиску 18 атм.

Табличя 2

Оцінка зразків кукурудзи на посухостійкість

методом набубнявіння насінин в осмотичному розчині $2 \mathrm{M} \mathrm{NaCl}$

\begin{tabular}{|c|c|c|c|c|c|c|c|c|c|}
\hline \multirow{3}{*}{ Зразки } & \multicolumn{2}{|c|}{2005 p. $\left(S_{4}\right)$} & \multicolumn{3}{|c|}{2006 p. $\left(\mathrm{S}_{5}\right)$} & \multicolumn{4}{|c|}{2007 p. $\left(S_{6}\right)$} \\
\hline & \multicolumn{9}{|c|}{ фон добору, \% води, поглинутої насінням } \\
\hline & контроль & 18 атм. & контроль & 18 атм. & 20 атм. & контроль & 18 атм. & 20 атм. & 22 атм. \\
\hline ПК 3 & $66,1 \pm 0,70$ & $70,1 \pm 1,00$ & $56,2 \pm 0,35$ & $54,8 \pm 1,31$ & $60,7 \pm 0,78$ & $58,1 \pm 1,66$ & $60,1 \pm 0,53$ & $57,6 \pm 0,25$ & $59,3 \pm 1,94$ \\
\hline ПК 7 & $45,4 \pm 0,67$ & $44,1 \pm 0,74$ & $46,3 \pm 0,58$ & $48,5 \pm 0,54$ & $43,0 \pm 0,04$ & $56,4 \pm 1,45$ & $55,8 \pm 0,92$ & $59,2 \pm 1,29$ & $59,0 \pm 2,19$ \\
\hline ПК 8 & $66,7 \pm 1,10$ & $72,6 \pm 0,53$ & $66,7 \pm 2,07$ & $77,0 \pm 0,07$ & $72,4 \pm 0,23$ & $67,9 \pm 1,45$ & $70,2 \pm 0,84$ & $72,1 \pm 0,57$ & $70,7 \pm 0,49$ \\
\hline ПК 9 & $61,8 \pm 1,05$ & $65,3 \pm 0,19$ & $65,8 \pm 0,11$ & $66,8 \pm 1,02$ & $75,0 \pm 0,66$ & $63,0 \pm 0,22$ & $62,7 \pm 1,35$ & $66,0 \pm 1,84$ & $72,5 \pm 0,73$ \\
\hline ПК 10 & $47,7 \pm 0,35$ & $55,9 \pm 1,14$ & $49,5 \pm 1,31$ & $48,7 \pm 1,45$ & $67,3 \pm 1,56$ & $49,7 \pm 1,10$ & $48,3 \pm 1,79$ & $54,9 \pm 1,7($ & $66,7 \pm 2,51$ \\
\hline ПК 12 & $56,5 \pm 0,48$ & $63,0 \pm 0,00$ & $58,8 \pm 3,25$ & $64,1 \pm 0,48$ & $65,7 \pm 0,65$ & $54,5 \pm 0,08$ & $62,8 \pm 0,04$ & $58,8 \pm 0,40$ & $57,1 \pm 0,42$ \\
\hline ПК 13 & $48,9 \pm 0,25$ & $50,4 \pm 1,25$ & $43,6 \pm 0,25$ & $51,5 \pm 0,00$ & $42,0 \pm 0,66$ & $55,7 \pm 2,74$ & $55,0 \pm 2,31$ & $56,2 \pm 0,96$ & $56,3 \pm 0,21$ \\
\hline ПК 15 & $59,1 \pm 0,29$ & $63,9 \pm 0,67$ & $65,8 \pm 1,66$ & $70,0 \pm 0,40$ & $69,9 \pm$ & 1,74 & $59,9 \pm 0,99$ & $59,4 \pm 0,57$ & $63,4 \pm 0,29$ \\
\hline ПК 16 & $57,7 \pm 0,89$ & $57,7 \pm 0,24$ & $53,8 \pm 1,03$ & $50,4 \pm 1,84$ & $53,2=$ & 0,15 & $58,7 \pm 1,70$ & 56,8 & 59,6 \\
\hline ПК 17 & $45,3 \pm 0,73$ & $48,3 \pm 0,46$ & $51,0 \pm 1,13$ & $53,0 \pm 0,80$ & $51,0 \pm 0,22$ & $57,0 \pm 1,70$ & $63,6 \pm 1,70$ & $61,2=$ & $64,4 \pm 1,53$ \\
\hline ПК 18 & $48,7 \pm 1,18$ & $56,3 \pm 0,11$ & $61,3 \pm 0,83$ & $63,8 \pm 0,74$ & 24 & 1,45 & $57,9 \pm 0,57$ & $53,2 \pm 0,61$ & $59,7 \pm 2,09$ \\
\hline ПК 19 & $61,8 \pm 0,35$ & $65,5 \pm 0,33$ & $55,1 \pm 2,32$ & $57,9 \pm 0,53$ & $61,6 \pm 0,43$ & $53,9 \pm 1,40$ & $53,4 \pm 0,29$ & $53,1 \pm 2,43$ & $56,5 \pm 0,27$ \\
\hline ПК 26 & $58,0 \pm 1,32$ & $58,3 \pm 0,55$ & $48,7 \pm 1,04$ & $49,4 \pm 0,37$ & $58,7 \pm 2,62$ & $46,7 \pm 0,92$ & $51,2 \pm 2,47$ & $54,3 \pm 0,41$ & $56,7 \pm 2,55$ \\
\hline ПК 27 & $53,7 \pm 0,96$ & $63,2 \pm 2,23$ & $46,0 \pm 0,48$ & $48,2 \pm 0,11$ & $51,5 \pm 0,71$ & $49,3 \pm 0,04$ & $56,3 \pm 1,30$ & $58,2 \pm 0,0$ & $63,5 \pm 0,71$ \\
\hline ПК 28 & $53,4 \pm 1,16$ & $60,7 \pm 0,33$ & $59,2 \pm 0,18$ & $60,6 \pm 0,51$ & $70,2 \pm 1,47$ & $60,6 \pm 0,71$ & $62,6 \pm 0,43$ & $59,6 \pm 2,05$ & $69,8 \pm 0,42$ \\
\hline ПК 29 & $47,9 \pm 0,78$ & $50,5 \pm 0,07$ & $55,2 \pm 2,52$ & $58,3 \pm 0,50$ & $52,8 \pm 0,08$ & $56,9 \pm 0,74$ & $62,8 \pm 0,28$ & $58,4 \pm 0,39$ & $57,0 \pm 0,60$ \\
\hline ПК 30 & $38,8 \pm 0,80$ & $36,7 \pm 0,44$ & $42,7 \pm 0,31$ & $57,4 \pm 1,20$ & $51,6 \pm 1,81$ & $53,4 \pm 0,64$ & $62,4 \pm 0,15$ & $61,8 \pm$ & $63,1 \pm 0,28$ \\
\hline ПК 31 & $50,2 \pm 0,74$ & $49,8 \pm 1,09$ & $43,6 \pm 1,08$ & $47,5 \pm 0,74$ & $49,1 \pm 0,31$ & $44,7 \pm 1,66$ & $50,3 \pm 2,05$ & $54,2 \pm 0,47$ & $45,4 \pm 0,95$ \\
\hline ПК 32 & $60,9 \pm 1,28$ & $64,0 \pm 0,49$ & $61,0 \pm 3,00$ & $69,2 \pm 2,37$ & $68,9 \pm 0,74$ & $49,2 \pm 2,16$ & $50,9 \pm 1,40$ & $58,7 \pm 0,97$ & $61,9 \pm 0,75$ \\
\hline ПК 33 & $34,7 \pm 1,48$ & $60,4 \pm 0,51$ & $45,5 \pm 1,80$ & $64,8 \pm 3,07$ & $47,6 \pm 0,74$ & $45,8 \pm 0,04$ & $52,5 \pm 2,08$ & $54,3 \pm 0,64$ & $55,8 \pm 0,00$ \\
\hline ПК 35 & $49,8 \pm 1,00$ & $48,8 \pm 2,02$ & $53,3 \pm 1,10$ & $50,0 \pm 0,82$ & $52,2 \pm 3,38$ & $40,6 \pm 1,63$ & $39,8 \pm 2,13$ & $44,2 \pm 0,19$ & $48,3 \pm 1,31$ \\
\hline ПК 40 & $60,0 \pm 1,02$ & $61,9 \pm 2,11$ & $52,1 \pm 2,48$ & $53,0 \pm 0,42$ & $65,9 \pm 2,72$ & $53,4 \pm 1,38$ & $53,8 \pm 1,94$ & $59,5 \pm 2,32$ & $64,5 \pm 0,39$ \\
\hline ередне & 53,3 & 57,6 & 53,7 & 57,5 & 59,1 & 54,0 & 57,0 & 57,9 & 60,4 \\
\hline $\mathrm{HIP}_{0,05}$ & 2,0 & 2,3 & 3,7 & 2,7 & 3,2 & 3,2 & 3,2 & 2,7 & 3,0 \\
\hline $\begin{array}{l}\mathrm{HIP}_{0,05} \text { за } \\
\text { групами }\end{array}$ & \multicolumn{2}{|c|}{1,9} & \multicolumn{3}{|c|}{3,5} & \multicolumn{4}{|c|}{3,3} \\
\hline
\end{tabular}

Примітки: $\mathrm{HIP}_{0,05}$ - найменша істотна різниця за Б. А. Доспєховым; контроль - контрольні рослини; 18, 20, 22 атм. - осмотичний тиск фону добору; ПК 3 - ПК 40 - робоча назва зразків; $\mathrm{S}_{4}-\mathrm{S}_{6}-$ цикл самозапилення ліній у процесі їх створення.

Добір проростків у розчинах сахарози при створенні ліній дозволяє виділити форми з особливими метаболічними перебудовами процесу проростання. Підвищення здатності поглинати важкодоступну воду (з осмотичних розчинів або у природних умовах при іiі нестачі у грунті) зумовило зростання осмотичної сили при набубнявінні насінин. Поступове збільшення концентрації сахарози як фону добору викликає зростання сисної сили проростків.

Зміни реакції зразків за роками відбуваються за рахунок різної якості зерна та погодних умов. Тому кожного року необхідно порівнювати дослідні форми з контрольними (які не підлягали добору), що забезпечить повнішу інформацію для вивчення стійкості генотипів.

Метод набубнявіння досить чітко розподіляє вихідний матеріал за ступенем сисної сили у насіння. До того ж, порівняно із попереднім методом, виключає похибку візуального визначення показника. Тому він надійніший для діагностики зразків за по- 
сухостійкістю проростаючого насіння, але не дає змоги дорощувати стійкі зразки та проводити добір, на відміну від методу пророщення на осмотичних розчинах.

Параметри водного режиму рослин у літній період досліджували в динаміці - це забезпечує детальнішу характеристику вихідного матеріалу та дає змогу виявити зміни метаболічних перебудов у рослинах на різних етапах онтогенезу. Кількість зв'язаної води за наведеними результатами (рис. 2) більша у рослин, які пройшли добір. Кожен рік форми, які відбирали на фоні сахарози підвищеної концентрації, мали більший вміст зв'язаної води.

У процесі онтогенезу рослин відбуваються зміни фракційного складу води. Крім того, при старінні зменшується різниця за вмістом зв'язаної води між відібраними та невідібраними рослинами. У сприятливих умовах вегетації рівень зв'язаної води вищий порівняно зі стресовими. У 2004 р., який характеризувався великою кількістю опадів та сприятливою температурою, середня кількість зв'язаної води в усіх форм була більшою, ніж в інші роки. У 2005 р. несприятливі погодні умови, які спостерігались у II та III фазі дослідження зразків, вплинули на водний стан рослин. Посуха сприяла виділенню стійких форм: стрес дозволив виявити відносне зростання зв'язаної води у рослин, відібраних на фоні 20 атм. (у фазі цвітіння волоті - на 4,8 \%, у фазі молочної стиглості - на 4,3 \%). Найменшою кількістю зв'язаної води характеризувались зразки у 2006 р. через значну посуху. Погодні умови дозволили детальніше проаналізувати i визначити рівень стійкості рослин до зневоднення. Максимальне зростання вмісту зв'язаної води було у рослин, відібраних на фоні 22 атм. (5,6, 4,7 та 4,8 \% відповідно до фаз досліджень).

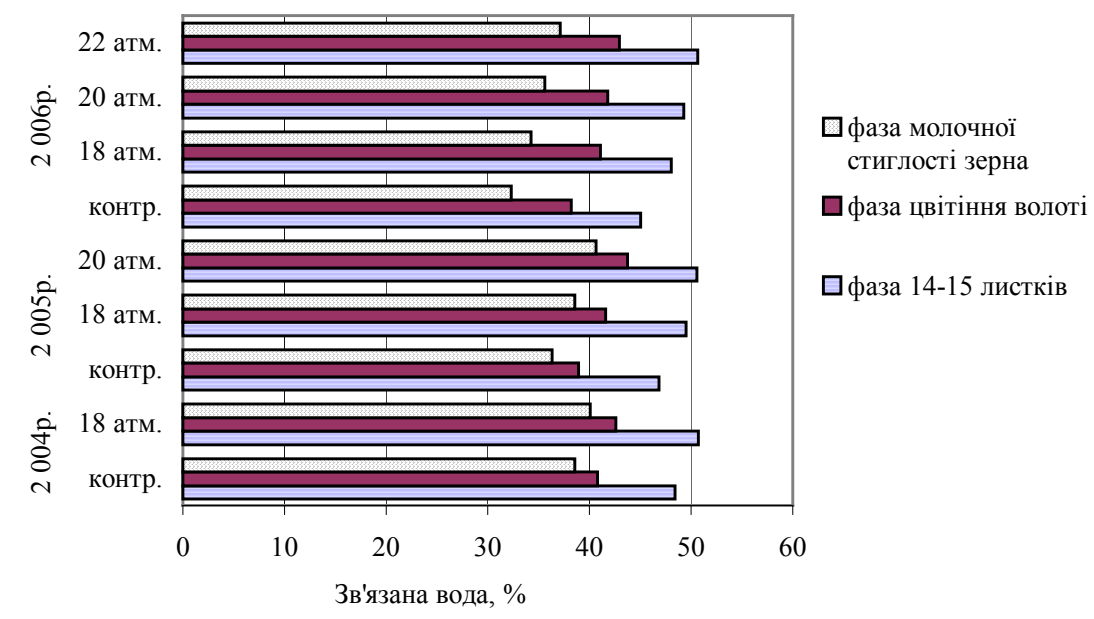

Рис. 2. Вміст зв'язаної води (\%) у листках рослин, відібраних на розчинах сахарози із різним ступенем тиску (2004-2006 рр.)

Відомо, що здатність утримувати та економно споживати воду в умовах посухи $\epsilon$ захисно-пристосувальною реакцією стійких рослин. Тому висока водоутримувальна здатність листків, зумовлена високим вмістом зв'язаної води, має суттєве значення для адаптації рослин до дії посухи. У даній роботі її визначали методом прив'ялювання зрізаних листків [1]. Як і фракційний склад води, рівень водоутримувальної здатності вказує на стан водного режиму рослин. Але, на відміну від констатації факту кількості води у тканинах листків, цей метод моделює штучну посуху, яка характеризується вмістом води до (контроль) та після в'янення (дослід). Параметри водоутримувальної здат- 
ності базуються на вимірах втрати води відносно загального ії вмісту. Тобто визначається не насичення тканин водою, а здатність зберігати іiі у період в'янення.

У дослідних рослин спостерігається значна тенденція до більшої втрати води зразками, які не підлягали добору (рис. 3). Значна водоутримувальна здатність свідчить про досить високий вміст зв'язаної води у тканинах листків (що підтверджується безпосереднім іiі визначенням). У середньому контрольні генотипи у процесі вегетації швидше втрачають тургор. Такі зразки за дії посухи мають недостатню кількість води для відновлення оптимальних процесів життєдіяльності, у клітинах таких рослин швидше починаються руйнівні процеси. Генотипи, в яких визначена висока спадкова водоутримувальна здатність, можна рекомендувати для залучення у селекційний процес при створенні посухостійких гібридів.

Посуха на всіх етапах досліджень у 2006 р. спричинила зростання втрати води як у контрольних, так і у відібраних рослин. Максимально ефективним виявився добір на фоні 3 тиском 20 атм. у 2005 р. (зростання водоутримувальної здатності упродовж вегетації відмічено у середньому від 6,2 до 9,2 \% порівняно з контрольними рослинами). Щодо зміни вологовіддачі у динаміці - у кожну наступну фазу за всіх фонів добору протягом трьох років рівень водоутримувальної здатності підвищувався у відібраних зразків відносно контролю. Тобто спостерігалось зберігання води відібраними рослинами у процесі розвитку.

До методів діагностики посухостійкості рослин відноситься також метод визначення зміни електричного опору тканин листків (ЕОТЛ) після дії посухи порівняно 3 контролем. Аналіз отриманих даних показав, що під впливом підсушування знижувався вміст води в листках рослин. Швидка втрата води у період активного росту та формування зерна свідчить про меншу пристосованість рослин. Зміна ЕОТЛ має зворотну залежність від втрати води. Під впливом посухи параметри ЕОТЛ значно змінюються. Це пов'язано з адаптаційною здатністю рослин до втрати вологи. Посухостійким зразкам властиві низькі значення зміни ЕОТЛ після дії посухи. Відібрані в осмотичних розчинах зразки мають більшу пристосованість до умов посухи за рахунок меншої зміни ЕОТЛ на різних фазах розвитку (рис. 4).

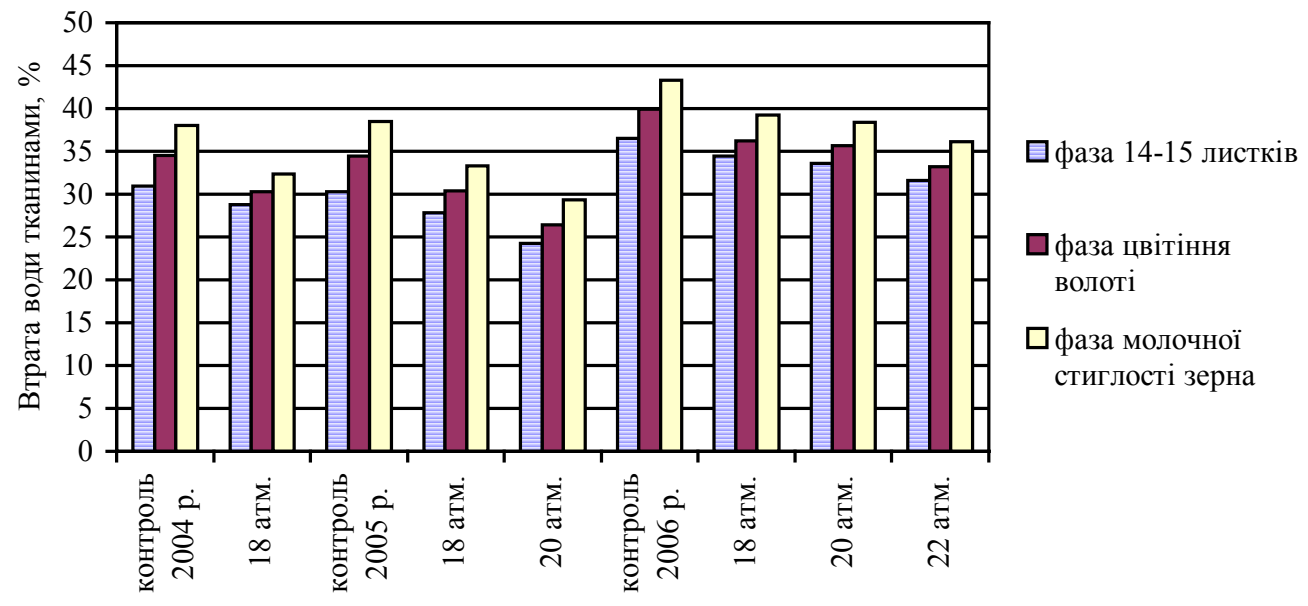

Рис. 3. Водоутримувальна здатність тканин листків рослин (\%), відібраних на розчинах сахарози з різним ступенем тиску (2004-2006 pp.) 


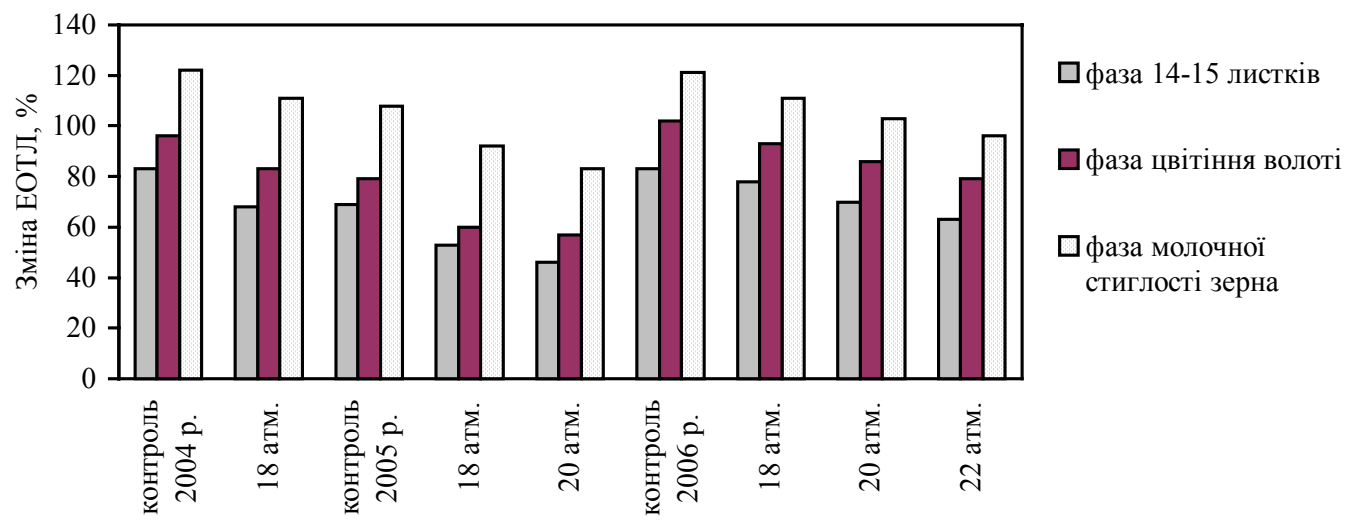

Рис. 4. Зміна електричного опору тканин листків (\%) у рослин, відібраних на розчинах сахарози із різним ступенем тиску (2004-2006 рр.)

\section{Висновки}

Форми, пророщені на осмотичних розчинах сахарози, мають більшу сисну силу, що дозволяє їм використовувати та зберігати більшу кількість води за умов дії посухи. Добір зразків на осмотичних розчинах сахарози підвищує їх посухостійкість за рахунок зростання вмісту зв'язаної води та меншої ії віддачі в умовах нестачі вологи. Визначено, що кращим фоном для добору на посухостійкість при використанні розчину сахарози $є$ поступове збільшення концентрації з осмотичним тиском від 18 до 22 атм. Зразки ПК 28-22, ПК 31-22, ПК 33-22, ПК 40-22 рекомендуються для використання у селекційній практиці створення посухостійких гібридів.

\section{Бібліографічні посилання}

1. Агроклиматические особенности и краткая характеристика почв Опытного хозяйства ВНИИ кукурузы / Ю. Е. Кизяков, Н. В. Гвиненко, В. В. Турчин, А. Г. Мусатов // Приемы повышения продуктивности кукурузы и озимой пшеницы в степи УССР. - Д., 1974. - С. 18-19.

2. Варасова Н. А. Физиология растений / Н. А. Варасова, А. П. Шустова. - Л. : Колос, 1969. - 224 с.

3. Гусев Н. А. Некоторые методы исследования водного режима растений. - Л. : Всесоюзн. ботан. о-во, 1960. - С. 3-10.

4. Доспехов В. А. Методика полевого опыта. - М. : Агропромиздат, 1985. - 351 с.

5. Методика диагностики селекционного материала для отбора кукурузы на адаптивную устойчивость (засухо-, жаро-, холодоустойчивость, устойчивость к загущению) / Г. Л. Филиппов, Н. В. Вишневский, В. А. Губенко, Л. А. Максимова. - Д. : ВНИИ кукурузы, 1989. - С. 3-5.

6. Методические указания по определению жаро- и засухоустойчивости кукурузы. - Д. : ВНИИ кукурузы, 1979. - С. 5-7.

7. Методические указания по комплексной оценке засухоустойчивости самоопыленных линий и гибридов кукурузы. - Л. : ВИР, 1981. - 20 с.

8. Моргун В. В. Фізіолого-генетичні проблеми селекції рослин у зв'язку з глобальними змінами клімату / В. В. Моргун, Т. М. Шадчина, Д. А. Кірізій // Физиология и биохимия культ. растений. - 2006. - Т. 38, № 5. - С. 371-389.

9. Molecular genetics of heat tolerance and heat shock proteins in cereals / E. Maestri, N. Klueva, C. Perrotta et al. // Plant Mol. Biol. - 2002. - Vol. 48. - P. 667-681.

Надійшла до редколегії 25.02.2009 